\title{
Relation of Age, Race, and Allotype to Immunoglobulin Subclass Concentrations
}

\author{
PENELOPE G. SHACKELFORD, DAN M. GRANOFF, MOON H. NAHM, MITCHELL G. SCOTT, \\ BRIAN SUAREZ, JANARDAN P. PANDEY, AND SUSAN J. NELSON
}

Departments of Pediatrics [P.G.S., D.M.G., S.J.N.], Pathology [M.H.N., M.G.S.], and Psychiatry [B.S.], Washington University School of Medicine; Division of Infectious Diseases, St. Louis Children's Hospital, St. Louis, Missouri 63178 and Department of Basic \& Clinical Immunology and Microbiology [J.P.P.], Medical University of South Carolina, Charleston, South Carolina

\begin{abstract}
Concentrations of $\operatorname{IgG}_{1}, \operatorname{IgG}_{2}$, and total $\operatorname{IgG}$ were measured by a solid phase radioimmunoassay in sera from 36 healthy adults and 114 healthy children. As expected, $\operatorname{IgG}_{2}$ and total $\operatorname{IgG}$ had a positive correlation with age in children. In addition to age, several other factors were associated with significant differences in serum subclass concentrations. Female children had higher concentrations of $\mathrm{IgG}_{1}$ than males, and black subjects had significantly higher concentrations of $\operatorname{IgG}_{\mathbf{1}}, \mathrm{IgG}_{2}$, and total IgG than whites. Although $\mathrm{Km}(1)$ and $\mathrm{Gm}(23)$ immunoglobulin allotypes had no relation to subclass concentrations when tested as single factors, the $\mathrm{Km}(1)$ allotype interacted significantly with race so that $\mathrm{Km}(1)$-positive black children had higher $\operatorname{IgC}_{2}$ concentrations than other subjects. Our findings may explain, in part, recent observations of an association of the $\mathrm{Km}(1)$ allotype with altered immune responses of blacks to certain vaccines containing bacterial polysaccharides. In addition, our data indicate the need to control factors such as sex, race, and allotype in studies of subclass concentrations or immune responses. (Pediatr Res 19: $846-849,1985$ )
\end{abstract}

\section{Abbreviations}

ANOVA, analysis of variance

ANCOVA, analysis of covariance

Hib, Haemophilus influenzae type b

Human IgG immunoglobulins have been divided antigenically into four subclasses, $\operatorname{IgG}_{1}, \operatorname{IgG}_{2}, \operatorname{IgG}_{3}$, and $\operatorname{IgG}_{4}$ (1-3). Of these, $\mathrm{IgG}_{1}$ and $\mathrm{IgG}_{2}$ comprise the major portion of total $\mathrm{IgG}, 60$ and $30 \%$, respectively. Although the biological importance of the four IgG subclasses is unknown, studies of myeloma proteins have revealed that these subclasses differ in their relative abilities to fix complement, to cross the placenta, and to bind to macrophages (4-6). In addition, antibodies to certain types of antigens, such as polysaccharides, are found to be relatively restricted to particular subclasses, i.e. $\operatorname{IgG}_{2}$ in humans $(7,8)$ and $\mathrm{IgG}_{3}$ in mice $(9,10)$. Finally, striking differences in the ontogeny of subclasses have been reported, with $\mathrm{IgG}_{2}$ and $\mathrm{IgG}_{4}$ maturing much later than $\operatorname{lgG}_{1}$ and $\operatorname{IgG}_{3}$ in normal children (11-13).

Received October 12, 1984: accepted March 27, 1985.

Address reprint requests to Penelope G. Shackelford, Department of Pediatrics. Washington University School of Medicine. Box 14871. St. Louis, MO 63178.

Supported by Public Health Service Grants R01-AI 19350, R01-AI 17962, AI 18727, AI 19676, MH 31302 and MH 14677 from the National Institutes of Health and by RR-36 from the General Clinical Research Center Branch.
It is known that antipolysaccharide antibodies play an important role in protective immunity against polysaccharide encapsulated bacterial pathogens (14-16). Recent studies indicate that genetic factors, particularly genes associated with certain Gm and/or $\mathrm{Km}$ immunoglobulin allotypes, may be associated with altered responsiveness to vaccines containing bacterial polysaccharides (17-19). In addition, black children lacking the $\mathrm{Km}(1)$ allotype have an increased relative risk of developing meningitis caused by Hib (17). Since human antipolysaccharide antibodies have been reported to be relatively restricted to the $\mathrm{IgG}_{2}$ subclass, it was of interest to determine if factors which appear to influence the production of antipolysaccharide antibodies, i.e. race and immunoglobulin allotype, might do so by virtue of their relation to the maturation and distribution of $\mathrm{IgG}$ subclasses in serum.

In this study, we first established normal age-group values for serum concentrations of $\mathrm{IgG}, \mathrm{IgG}_{1}$, and $\mathrm{IgG}_{2}$ in our laboratory. We then examined the effects of sex, race, and $\mathrm{Km}(1)$ and $\mathrm{Gm}(23)$ allotypes on these immunoglobulin concentrations in a group of children ages 7 to 38 months and in adults. We found that black subjects, particularly those with certain immunoglobulin allotypes, had higher serum concentrations of $\operatorname{IgG}, \operatorname{lgG}_{1}$, and $\operatorname{lgG}_{2}$.

\section{METHODS}

Subjects. Normal subjects included 41 healthy adults and 114 healthy children, 7 months through $16 \mathrm{yr}$ of age. These subjects were participants in various vaccine studies, or were recruited sequentially from among children presenting to a pediatric office for routine preventive care. Subjects in vaccine studies were included based on availability of sera and race (to include equal numbers of blacks and whites). In order to increase the sample size of sera from subjects with allotypes present in low numbers in the above sample [e.g. $\mathrm{Km}(1)$ positive whites and $\mathrm{Km}(1)$ negative blacks], we also included 10 serum samples that had previously been typed for $\mathrm{Gm}(23)$ and $\mathrm{Km}(1)$. After obtaining informed consent, serum was collected by venipuncture and stored at $-20^{\circ} \mathrm{C}$.

Laboratory methods. Serum $\operatorname{IgG}_{1}$ and $\mathrm{IgG}_{2}$ subclass concentrations were measured by a solid phase radioimunoassay (20) employing subclass specific reagents. In brief, a monoclonal antihuman $\operatorname{IgG}_{1}$ reagent was prepared by immunization of a BALB/C mouse with "Cal," an $\mathrm{IgG}_{1}$ myeloma protein (20). An antihuman $\mathrm{IgG}_{2}$ reagent was prepared by immunization of a monkey (Macaca fasicularis) with two $\mathrm{IgG}_{2}$ myeloma proteins, "Ziem" $\left(\operatorname{IgG}_{2} \mathrm{k}\right)$ and "Gar" $\left(\operatorname{IgG}_{2} \lambda\right)(20)$. The animal was primed with $\mathrm{Fc}$ fragments and boosted with intact protein. Serum was rendered $\mathrm{IgG}_{2}$ specific by extensive absorption and affinity pu- 
rification using $\mathrm{IgG}_{1}$ and $\mathrm{IgG}_{2}$ conjugated sepharose $4 \mathrm{~B}$ (Pharmacia, Piscataway, NJ) columns, respectively. Polyvinyl 96-well microtiter plates (Dynatech, Alexandria, VA) were coated with subclass-specific antisera in phosphate-buffered saline. After coating with antiserum, plates were washed with $0.05 \%$ Tween 20 in normal saline and uncoated sites were blocked with $1 \%$ bovine serum albumin. Serum and myeloma standards were added to the plates and serial 4-fold dilutions were performed in the plate. A proband myeloma, radiolabeled with ${ }^{125}$ I by the chloramine T method (21), was added to each well. The plates were incubated overnight at room temperature, washed, and individual wells were counted. The concentration of $\operatorname{IgG}_{1}$ or $\operatorname{IgG}_{2}$ was calculated by comparison with the myeloma standard.

The specificity of the $\mathrm{IgG}_{1}$ and $\mathrm{IgG}_{2}$ assays was confirmed using a panel of 39 purified human myeloma proteins (20). The World Health Organization reference serum 67/97 (IgG content $7700 \mu \mathrm{g} / \mathrm{ml}$ ) was included in each assay as an internal control. The mean $\pm \mathrm{SD}$ value $(\mu \mathrm{g} / \mathrm{ml})$ determined for $\mathrm{IgG}, \mathrm{IgG}_{1}$ and $\mathrm{IgG}_{2}$ in this reference serum, using our assays, compared well to those previously published (22) (in parentheses): $\operatorname{IgG} 8050 \pm 332$ (9000), $\operatorname{IgG}_{1} 6113 \pm 1273(5100)$, and $\operatorname{IgG}_{2} 2390 \pm 285(2500)$. The sensitivity of each assay was equal to the amount of standard protein which resulted in $50 \%$ inhibition of maximum binding. For $\operatorname{lgG} \mathrm{G}_{1}$ this ranged from $50-129 \mathrm{ng} / \mathrm{ml}$ and for $\mathrm{IgG}_{2}$ from $70-$ $200 \mathrm{ng} / \mathrm{ml}$.

Determination of the $\mathrm{Gm}(23)$ and $\mathrm{Km}(1)$ allotypes was performed on coded serum samples, using a hemagglutination inhibition assay with reagents described previously $(23,24)$. Sufficient sera for analysis was available from 36 adults and 64 children less than 38 months of age.

The concentration of total $\operatorname{IgG}$ in serum was measured by radial immunodiffusion using the kinetic (Fahey) method and commercial kits (ICL Scientific, Fountain Valley, CA).

Statistical analysis. Statistical analysis was performed using SPSS programs (25) on a Harris 500 computer. Correlation analysis was used to assess the association between age and immunoglobulin concentration. ANOVA was used to test for differences in immunoglobulin concentrations among all subjects when grouped by age and among adults grouped by sex, race, or allotype. To allow for multiple comparisons, the Scheffe procedure was used to compare the age group means. For children, ANCOVA was used to remove the effect of age when testing for mean differences based on sex, race, or allotype.

Normal values for immunoglobulin concentrations for the various age groups are expressed as geometic means. The normal range for each age group was determined by taking the antilog of mean logarithm ( $\pm 2 \mathrm{SD}$ of the logarithms).

\section{RESULTS}

The geometric mean $\operatorname{IgG}_{1}, \operatorname{IgG}_{2}$, and $\operatorname{IgG}$ concentrations in groups of normal subjects of various ages are shown in Table 1. As previously reported $(11,12)$, serum concentrations of $\operatorname{lgG}_{1}$ increase rapidly during the $1 \mathrm{st}$ yr of life. Even in the youngest age group in this study ( $7-12$ months) the concentrations were not significantly lower than those of adults.

The maturation of serum $\mathrm{IgG}_{2}$ concentration differed considerably from that of $\operatorname{IgG}_{1}$. In children 7-12 months of age, the mean concentration of $\mathrm{IgG}_{2}$ was $30 \%$ of the adult value and rose to only $47 \%$ of the adult value by $31-36$ months of age. Another measure of the prominent age-effect on $\mathrm{IgG}_{2}$ was the positive correlation with age in children less than 38 months of age $(r=$ $0.46, p<0.001)$; in contrast, the correlation $(r=0.07)$ between age and $\operatorname{IgG}_{1}$ was not significantly different from zero. Total serum $\operatorname{IgG}$ correlated with age in children less than 38 months of age $(r=0.37, p=0.002)$.

The effects of sex, race, and the $\mathrm{Gm}(23)$ and $\mathrm{Km}(1)$ immunoglobulin allotypes on serum $\operatorname{IgG}_{1}, \mathrm{IgG}_{2}$, and $\mathrm{IgG}$ concentrations were tested. Data were analyzed separately for children and for adults. Children 7-38 months of age were chosen because of
Table 1. $\operatorname{Ig} G_{1}, \operatorname{Ig} G_{2}$, and $\operatorname{Ig} G$ concentrations in sera from 114 normal children and 41 healthy adults

\begin{tabular}{ccccc} 
& & \multicolumn{3}{c}{ Geometric mean $(\mu \mathrm{g} / \mathrm{ml})$} \\
\cline { 4 - 5 } Age $(\mathrm{mo})$ & $n$ & $\mathrm{IgG}_{1}$ & $\mathrm{IgG}_{2}$ & $\mathrm{IgG}$ \\
\hline $7-12$ & 7 & 3655 & $767^{*}$ & $6206^{*}$ \\
& & $(1541-8666) \dagger$ & $(260-2265)$ & $(2805-13,703)$ \\
$13-18$ & 19 & 5992 & $891^{*}$ & $8232^{*}$ \\
& & $(2126-16,889)$ & $(368-2155)$ & $(3808-17,795)$ \\
$19-24$ & 16 & 7058 & $1020^{*}$ & 9524 \\
& & $(3416-14,585)$ & $(323-3226)$ & $(5383-16,850)$ \\
$25-30$ & 11 & 5924 & 1390 & 9900 \\
& & $(4144-8468)$ & $(703-2746)$ & $(5302-15,431$ \\
$31-36$ & 12 & 4914 & $1187^{*}$ & 9143 \\
& & $(1435-16,819)$ & $(656-2150)$ & $(4439-18,832)$ \\
$37-60$ & 11 & 5806 & 1344 & 8215 \\
& & $(3833-8796)$ & $(444-4071)$ & $(4025-16,765)$ \\
$61-84$ & 10 & 5129 & 1601 & 10,245 \\
& & $(2587-10,195)$ & $(510-5027)$ & $(5120-20,497)$ \\
$85-108$ & 7 & 6601 & 1363 & 11,327 \\
& & $(3242-13,440)$ & $(443-4191)$ & $(6461-19,856)$ \\
$109-156$ & 9 & 5853 & 1646 & 10,271 \\
& & $(3337-10,266)$ & $(466-5806)$ & $(6789-15,538)$ \\
$157-203$ & 12 & 7695 & 2024 & 11,652 \\
& & $(3270-18,105)$ & $(745-5498)$ & $(6155-22,059)$ \\
& & & & \\
Adults & 41 & 6561 & 2551 & 12,410 \\
& & $(3552-12,067)$ & $(878-7398)$ & $(6616-23,281)$ \\
\hline
\end{tabular}

* Indicates a value for the age group which is significantly different by the Scheffe' procedure $(p \leq 0.05)$ from the corresponding adult values.

$\dagger$ The normal bounds in parentheses were determined by taking the antilog of (mean logarithm \pm 2 SD of the logarithms).

Table 2. Immunoglobulin concentrations in normal subjects: relation to sex

\begin{tabular}{lcccc} 
& \multicolumn{4}{c}{ Mean Ig concentrations $(\mu \mathrm{g} /$} \\
& & \multicolumn{3}{c}{$\mathrm{ml})$} \\
\cline { 3 - 5 } & $n$ & $\mathrm{IgG}_{1}$ & $\mathrm{IgG}_{2}$ & $\mathrm{IgG}$ \\
\hline Children & & & & \\
$\quad$ Male & 25 & $5338^{*}$ & 1127 & 8445 \\
$\quad \begin{array}{l}\text { Female } \\
\text { Adults }\end{array}$ & 39 & $7044^{*}$ & 1140 & 8835 \\
$\quad$ Male & & & & \\
$\quad$ Female & 18 & 7437 & 3025 & 12,364 \\
\hline
\end{tabular}

$* p=0.02$ by 1 -way ANCOVA with age as a covariate.

the significant linear correlation between age and both $\mathrm{IgG}$ and $\mathrm{IgG}_{2}$ serum concentrations in these subjects. This correlation permitted the use of ANCOVA to test for the effects of sex, race, or immunoglobulin allotype on immunoglobulin concentrations in young children while controlling for age.

Female children were found to have significantly higher $(p=$ 0.02 ) serum concentrations of $\mathrm{IgG}_{1}$ than males (Table 2 ). In adults, there were no significant differences in the serum concentrations of $\operatorname{IgG}_{1}, \operatorname{IgG}_{2}$, or total $\mathrm{IgG}$ between males and females.

We used 2-way ANOVA and ANCOVA to test for both main and interactive effects of race and immunoglobulin allotypes on serum concentrations of $\mathrm{IgG}_{1}, \mathrm{IgG}_{2}$, and $\mathrm{IgG}$. As summarized in Table 3, 2-way analysis of the relation of immunoglobulins to $\mathrm{Km}(1)$ and race showed no significant differences in $\mathrm{gG}_{1}$ concentrations between subjects of different races although there was a trend for $\operatorname{IgG}_{1}$ to be higher in blacks than in whites (for adults, $p=0.07$, and for children, $p=0.09$ ). $\operatorname{IgG}_{2}$ concentrations were significantly higher in black adults than in white adults ( $p$ $=0.02$ ). However, in children, this difference was apparent only in subjects with the $\mathrm{Km}(1)$ allotype $(p=0.02$, by ANCOVA 
Table 3. Immunoglobulin concentrations in normal subjects. relation to race and $K m(1)$ immunoglobulin allotype

\begin{tabular}{|c|c|c|c|c|}
\hline & \multirow[b]{2}{*}{$n$} & \multicolumn{3}{|c|}{ Mean Ig concentrations $(\mu \mathrm{g} / \mathrm{ml})$} \\
\hline & & $\lg G_{1}$ & $\mathrm{IgG}_{2}$ & IgG \\
\hline \multicolumn{5}{|l|}{ Children } \\
\hline \multicolumn{5}{|l|}{$\mathrm{Km}(1)^{-}$} \\
\hline White & 27 & 5832 & 1066 & 7806 \\
\hline Black & 12 & 6473 & 904 & 9334 \\
\hline \multicolumn{5}{|l|}{$\mathrm{Km}(1)^{+}$} \\
\hline White & 8 & 6407 & 1003 & 7691 \\
\hline Black & 17 & 7163 & 1470 & 10,082 \\
\hline \multicolumn{5}{|c|}{ Probabilities (2-way ANCOVA) } \\
\hline Main & & $\mathrm{NS}^{*}$ & NS & 0.02 (race) \\
\hline Interaction & & NS & 0.02 & NS \\
\hline \multicolumn{5}{|l|}{ Adults } \\
\hline \multicolumn{5}{|l|}{$\mathrm{K} \cdot \mathrm{m}(1)^{-}$} \\
\hline White & 16 & 6111 & 2113 & 11,591 \\
\hline Black & 7 & 7858 & 3450 & 13,337 \\
\hline \multicolumn{5}{|l|}{$\mathrm{Km}(1)^{+}$} \\
\hline White & 3 & 6530 & 2278 & 10,823 \\
\hline Black & 10 & 8005 & 4043 & 15,017 \\
\hline \multicolumn{5}{|c|}{ Probabilities (2-way ANOVA) } \\
\hline Main & & NS & 0.02 (race) & NS \\
\hline Interaction & & NS & NS & NS \\
\hline
\end{tabular}

* No significant difference.

Table 4. Immunoglobulin concentrations in normal subjects: relation to race and $G m(23)$ allotype

\begin{tabular}{|c|c|c|c|c|}
\hline & \multirow[b]{2}{*}{$n$} & \multicolumn{3}{|c|}{ Mean Ig concentrations $(\mu \mathrm{g} / \mathrm{ml})$} \\
\hline & & $\mathrm{IgG}_{1}$ & $\mathrm{IgG}_{2}$ & $\lg G$ \\
\hline \multicolumn{5}{|l|}{ Children } \\
\hline \multicolumn{5}{|l|}{$\operatorname{Gm}(23)^{-}$} \\
\hline White & 15 & 5337 & 1013 & 6769 \\
\hline Black & 23 & 6571 & 1314 & 9318 \\
\hline \multicolumn{5}{|l|}{$\operatorname{Gm}(23)^{+}$} \\
\hline White & 20 & 6434 & 1081 & 8538 \\
\hline Black & 6 & 8055 & 937 & 9891 \\
\hline \multicolumn{5}{|c|}{ Probabilities (2-way ANCOVA) } \\
\hline Main & & NS & NS & 0.006 (race) \\
\hline Interaction & & NS & NS & NS \\
\hline \multicolumn{5}{|l|}{ Adults } \\
\hline \multicolumn{5}{|l|}{$\operatorname{Gm}(23)^{-}$} \\
\hline White & 5 & 5693 & 1775 & 10,314 \\
\hline Black & 13 & 7568 & 4325 & 15,043 \\
\hline \multicolumn{5}{|l|}{$\operatorname{Gm}(23)^{+}$} \\
\hline White & 14 & 6350 & 2269 & 11,883 \\
\hline Black & 4 & 9167 & 2088 & 11,993 \\
\hline \multicolumn{5}{|c|}{ Probabilities (2-way ANOVA) } \\
\hline Main & & 0.02 (race) & 0.04 (race) & NS \\
\hline Interaction & & NS & 0.03 & NS \\
\hline
\end{tabular}

with age as the covariate). Black children had significantly higher concentrations of total IgG (mean $9973 \mu \mathrm{g} / \mathrm{ml}$ ) than white children $(7780 \mu \mathrm{g} / \mathrm{ml})(p=0.02)$. Although $\mathrm{IgG}$ concentrations also tended to be higher in black adults, this difference was not statistically significant $(p=0.07)$.

The effects of race and $\mathrm{Gm}(23)$ allotype on immunoglobulin concentrations are shown in Table 4. In this analysis, with $\operatorname{Gm}(23)$ as the second factor in the 2-way ANOVA, the higher mean concentration of $\operatorname{Ig}_{1}$ in black adults was statistically significant $(p=0.02)$. $\operatorname{IgG}_{1}$ concentrations also tended to be higher in black children than in white children $(p=0.09) . \operatorname{IgG}_{2}$ concentrations were again found to be significantly higher in black adults $(p=0.04)$. In addition, a significant interaction effect between race and $\mathrm{Gm}(23)$ allotype was found in black adults but not black children. Black adults who lacked the $\mathrm{Gm}(23)$ allotype had very high serum concentrations of $\mathrm{IgG}_{2}$ (mean $=4325 \mu \mathrm{g} / \mathrm{ml}$ ), approximately twice the mean concentrations of $\operatorname{IgG}_{2}$ in the other three adult groups. Finally, as in the 2way analysis with $\mathrm{Km}(1)$, serum concentrations of $\operatorname{IgG}$ were significantly higher in black children than in white children ( $p$ $=0.006$ ) and tended to be higher in black adults than in white adults $(p=0.07)$.

\section{DISCUSSION}

Employing solid phase inhibition assays, we obtained values for $\operatorname{IgG}_{1}$ and $\operatorname{IgG}_{2}$ which are similar to those previously reported (11-13). We developed these assays in order to test large numbers of samples, including some at low concentrations of IgG subclasses using small quantities of antisera (20). Our data confirm earlier observations of age-related changes in immunoglobulin concentrations, and indicate further that $\operatorname{IgG}_{1}$ and $\mathrm{IgG}_{2}$ concentrations are influenced by sex and race of the subject, and by the presence or absence of the $\mathrm{Km}(1)$ and $\mathrm{Gm}(23)$ allotypes.

Specifically, $\mathrm{IgG}_{2}$ concentrations were lower in children up to 108 months $(9 \mathrm{yr})$ of age than in adults. On the other hand, $\mathrm{IgG}_{1}$ concentrations of only the youngest children (7-12 months) were less than those of normal adults, and in older children concentrations of $\operatorname{IgG}_{1}$ were higher than in adults. Higher concentrations of $\mathrm{IgG}_{1}$ in older children have been noted in previous studies (13) and may reflect response to hyperimmunization resulting from routine childhood immunization and frequent infections.

Although normal age group values for $\mathrm{IgG}$, IgA, and IgM have been established separately for males and females, only one previous study of IgG subclass concentrations in children has addressed the possible influence of gender. Van Der Giessen et al. (13) found no significant differences in subclass concentrations between boys and girls more than 48 months of age. In our analysis of the values in children 7-38 months of age, we found significantly greater concentrations of $\mathrm{IgG}_{1}$ in females than in males. This difference was not noted in adults.

In 1968, Buckley et al. (26) reported significantly higher concentrations of $\operatorname{IgG}$ in black subjects 6 through $14 \mathrm{yr}$ of age compared to those in whites of comparable age. No significant differences in IgG concentrations were found in black and white children less than $6 \mathrm{yr}$ of age; however, no correction was made for age so the effect of race on IgG in this group of children may have been masked by inclusion of a greater proportion of blacks who were very young ( $<9$ months). Using ANCOVA to correct for age, we found that black children between 7 and 38 months of age had significantly higher serum concentrations of $\operatorname{IgG}$ than white children (Table 3). In addition, black adults had higher $\mathrm{IgG}_{1}$ and $\operatorname{lgG}_{2}$ concentrations than white adults. Although $\operatorname{IgG}_{1}$ tended to be higher in black children, serum $\mathrm{IgG}_{1}$ and $\mathrm{IgG}_{2}$ concentrations did not differ significantly in black and white children when only the single effect of race was tested.

Previous studies suggested an effect of immunoglobulin allotype on serum concentrations of $\operatorname{IgG}$ subclasses $(13,22,27)$ but the results were conflicting. In one study, both $\mathrm{IgG}_{2}$ and $\mathrm{IgG}_{4}$ concentrations were higher in persons with the $\mathrm{Gm}(23)$ phenotype (22). In a subsequent study (27) $\mathrm{IgG}_{4}$ but not $\mathrm{IgG}_{2}$ concentrations were increased in subjects with $\mathrm{Gm}(23)$ compared with the corresponding values of subjects lacking $\operatorname{Gm}(23)$. In a third study (13), mean $\operatorname{lgG}_{2}$ concentrations were higher in sera positive for $\operatorname{Gm}(23)$ than in sera lacking this allotype. In the present study, with one exception, there were no significant differences in subclass concentrations related to this allotype. The exception was higher $\operatorname{IgG}_{2}$ concentrations in black adults lacking $\operatorname{Gm}(23)$ (Table 3). However, the $\mathrm{Gm}(23)$ allotype, frequent in whites, is rarely found in African blacks (28). Thus, we believe that the relation of serum $\operatorname{IgG}_{2}$ concentrations with $\mathrm{Gm}(23)$ allotype in our North American blacks reflects the influence of racial admixture rather than an allotype effect, since black race itself was 
associated with higher $\operatorname{lgG}_{2}$ concentrations than white race, and $\mathrm{Gm}(23)$ was not associated with altered $\mathrm{IgG}_{2}$ concentrations in whites. However, another posibility is that genes associated with the $\mathrm{Gm}(23)$ locus are interacting with other gene products present in blacks, but not whites, and affecting $\operatorname{lgG}_{2}$ levels. For example, there are reports of interactive effects of allotype and major histocompatibility loci on immune responses (29-31), and in humans, the frequency of HLA specificities differs among races.

In this study, we found that black children who were $\mathrm{Km}(1)$ positive had significantly higher concentrations of $\operatorname{lgG}_{2}$ than black children who lacked this allotype (Table 3). Antibody against the polysaccharide capsule of $\mathrm{Hib}$ is protective against invasive disease (14-16). Further, antibodies to many other polysaccharide antigens are reported to be relatively restricted to the $\mathrm{IgG}_{2}$ subclass $(7,8)$. Recent studies suggest that genes associated with the $\mathrm{Km}(1)$ immunoglobulin allotype may influence the antibody response to vaccines containing bacterial polysaccharides (17-19). For example, black children with the $\mathrm{Km}(1)$ positive allotype have increased antibody responses to Hib polysaccharide-pertussis vaccine compared with those of blacks who lack this allotype (17). More recently, blacks with $\mathrm{Km}(1)$ also were found to have higher antibody responses to the purified type $\mathrm{b}$ polysaccharide (32). In addition, $\mathrm{Km}(1)$-positive black children had a lower relative risk of Haemophilus meningitis than blacks who lack this allotype (17). Thus, in blacks, high responsiveness to $\mathrm{Hib}$ vaccines and low susceptibility to $\mathrm{Hib}$ disease appear to be related to genes associated with the $\mathrm{Km}(1)$ locus. The present data suggest that these genes in turn may be associated with high concentrations of the $\mathrm{IgG}_{2}$ immunoglobulin subclass.

In conclusion, IgG subclass concentrations in children are influenced by many factors, the most important of which is age. It appears that race and the $\mathrm{Km}(1)$ immunoglobulin allotype also may affect serum concentrations of the late maturing $\operatorname{IgG}_{2}$ subclass. These data may explain, in part, recent observations of the asssociation of $\mathrm{Km}(1)$ immunoglobulin allotypes with different immune responses to vaccines containing polysaccharides. Our findings emphasize the need to control for factors such as race, sex, and immunoglobulin allotype in future studies assessing subclass concentrations and their possible influence on immunologic responses.

Acknowledgments. The authors thank Anthony Quinn, Jill Crouse, Audrey Wolf, and Kim Macke for excellent technical assistance.

\section{REFERENCES}

1. Dray $S 1960$ Threc gammaglobulins in normal human serum revealed by monkey precipitins. Science 132:1313-1314

2. Terry WD, Fahey JL 1964 Heterogeneity of $\mathrm{H}$ chains of human $7 \mathrm{~S}$ gammaglobulin. Fed Proc 23:454

3. Grey HM, Kunkel HG $1964 \mathrm{H}$ chain subgroups of myeloma proteins and normal 7S gammaglobulin. J Exp Med 120:253-266

4. Natvig JB, Kunkel HG 1973 Human immunoglobulins: classes, subclasses, genetic variants, and idiotypes. Adv Immunol 16:1 -.59

5. Spiegelberg HL 1974 Biological activities of immunoglobulins of different classes and subclasses. Adv Immunol 19:259-294

6. Shakib F, Stanworth DR 1980 Human IgG subclasses in health and disease Ric Clin Lab 10:463-479

7. Yount WJ, Dorner MM, Kunkel HG, Kabat EA 1968 Studies on human antibodies. VI. Selective variations in subgroup composition and genetic markers. J Exp Med 127:633-646
8. Riesen WF, Skvaril F, Braun DG 1976 Natural infection of man with group A streptococci. Scand J Immunol 5:383-390

9. Perlmutter R, Hansburg D, Briles D, Nicolotti R, Davie JM 1978 Subclass restriction of murine anticarbohydrate antibodies. J Immunol 121:566-57?

10. Slack J, DerBalian G, Nahm M, Davie JM 1980 Subclass restriction of murine antibodies. II. The IgG plaque forming cell response to thymus independen type 1 and type 2 antigens in normal mice and mice expressing an $x$-linked immunodeficiency. I Exp Med 151:853-862

11. Morell A, Skvaril F, Hitzig WH, Barandum S 1972 IgG subclasses: Development of the serum concentrations in "normal" infants and children. J Pedia1r 80:960-964

12. Schur PH, Rosen F, Norman ME 1979 Immunologic subclasses in normal children. Pediatr Res 13:181-183

13. Van Der Giessen M, Rossouw E, Algra-Van Veen T, Loghem E Van, Zegers BJM, Sander PC 1975 Quantification of IgG subclasses in sera of normal adults and healthy children between 4 and 12 years of age. Clin Exp Immunol 21:501-509

14. Anderson $P$, Johnston RB Ir, Smith $D H 1972$ Human serum activities against Haemophilus influenzae type b. J Clin Invest 51:31-44

15. Schneerson R, Rodrigues LP, Parke JC Jr, Robbins JB 1971 Immunity to disease caused by Haemophilus influenzae type b. II. Specificity and some biologic characteristics of "natural," infection-acquired, and immunizationinduced antibodies to the capsular polysaccharide of Haemophilus influenzue type b. J Immunol 107:1081-1089

16. Peltola H, Koyhty H, Sironen A, Mäkelä PH 1977 Haemophilus infuenzae type b capsular polysaccharide vaccine in children: A double-blind fieid study of 100,000 vaccinees three months to five years of age in Finland. Pediatrics $60: 730-737$

17. Granoff DM, Pandey JP, Boies E, Squires J, Munson RS Jr, Suarez B 1984 Response to immunization with Haemophilus influenzae type $\mathrm{b}$ polysaccha. ride pertussis vaccine and risk of Haemophilus meningitis in children with the $\mathrm{Km}(1)$ immunoglobulin allotype. J Clin Invest 74:1708-17 14

18. Pandey JP, Fundenberg HH, Virella G, Kyong CU, Loadholt CB, Galbraith RM, Gotschlich EC, Parke JC Jr 1979 Association between immunoglobulin allotypes and immune responses to Haemophilus infuenzae and meningococcus polysaccharides. Lancet 1:190-192

19. Ambrosino DM, Siber GR, Loghe E van, Schiffman G 1981 Increased antibody response to immunization with Haemophilus infuenzae type $b$ and preumococcal capsular polysaccharide vaccines in adults with $\mathrm{G} 2 \mathrm{M}(\mathrm{n})$ allotype. Pediatr Res 16:234A(abstr)

20. Scott MG, Nahm MH 1984 Mitogen induced human IgG subclass expression. J Immunol 133:2454-2460, 1984 .

21. Hunter WM, Greenwood FC 1962 Preparation of iodine-131 labeled human growth hormone of high specific gravity. Nature 194:495-496

22. Morrell A, Skvaril F, Steinberg AG, Loghem E van, Terry WD 1972 Correlations between the concentration of the four subclasses of IgG and $\mathrm{Gm}$ allotypes in normal human sera. J Immunol 108:195-206

23. Vyas GN, Fudenberg HH, Pretty HM, Gold ER 1968 A new rapid method for genetic typing of human imunoglobulins. J Immunol 100:274-279

24. Pandey JP, Shannon BT, Arala-Chaves MP, Fudenberg HH $1982 \mathrm{Gm}$ and $\mathrm{Km}$ frequencies in a Portugese population. Hum Genet 61:154-156

25. Nie NH, Hull CH, Jenkins JG, Steinbrenner K, Bent DH 1975 SPSS: Statistical Package for the Social Sciences. McGraw Hill, New York

26. Buckley RH, Dees SC, O'Fallon WM 1968 Serum immunoglobulins: 1. Levels in normal children and in uncomplicated childhood allergy. Pediatrics $41: 600-611$

27. Steinberg AG, Morell A, Skvaril F, Loghem E van 1973 The effect of $\mathrm{Gm}(23)$ on the concentration of $\mathrm{IgG}_{2}$ and $\mathrm{IgG}_{4}$ in normal human serum. $\mathrm{J} I \mathrm{~mm}$ monol $110: 1642-1645$

28. Grubb R 1970 The genetic markers of immunoglobulins. Molecular Biology Biochemistry and Biophysics, Vol 9. Springer-Verlag, New York

29. Granoff DM, Boies E, Squires J, Pandey JP, Suarez B, Oldfather J, Rodey GE 1984 Interactive effect of genes associated with immunoglobulin allotypes and HLA specificities on susceptibility to Haemophihs infuenzae disease. $J$ Immunogenet 11:181-188

30. Kagnoff MG 1982 Two genetic loci control the murine immune response to A-gliadin, a wheat protein that activates coeliac sprue. Nature 296:158-160

31. Whittingham S, Mathews JD, Schanfield MS, Matthews JV, Tait BD, Morris PJ, Mackay IR 1980 Interactive effect of Gm allotypes and HLA-B locus antigens on the human antibody response to a bacterial antigen. Clin Exp Immunol 40:8-15

32. Granoff DM, Boies EG, Pandey J 1985 Further studies of the responses to Haemophilus influenzae type b vaccine in relation to the $\mathrm{Km}(1)$ and $\mathrm{Gm}(23)$ allotypes. Pediatr Res 19:294A, 1985 